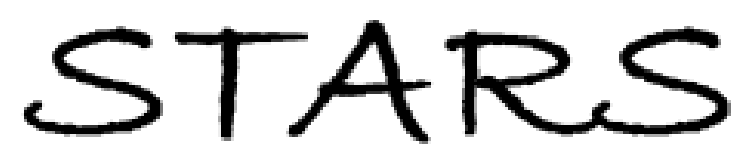

University of Central Florida

STARS

PRISM: Political \& Rights Issues \& Social Movements

$1-1-1950$

\title{
The Christian conscience and weapons of mass destruction
}

Federal Council of the Churches of Christ in America

Find similar works at: https://stars.library.ucf.edu/prism

University of Central Florida Libraries http://library.ucf.edu

This Book is brought to you for free and open access by STARS. It has been accepted for inclusion in PRISM: Political \& Rights Issues \& Social Movements by an authorized administrator of STARS. For more information, please contact STARS@ucf.edu.

\section{Recommended Citation}

Federal Council of the Churches of Christ in America, "The Christian conscience and weapons of mass destruction" (1950). PRISM: Political \& Rights Issues \& Social Movements. 429.

https://stars.library.ucf.edu/prism/429

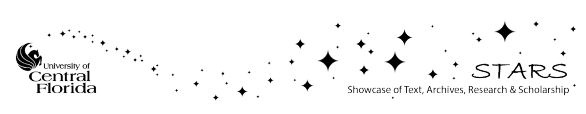




\section{THE CHRISTIAN CONSCIENCE AND WEAPONS OF MASS DESTRUCTION}

\section{REPORT OF A SPECIAL COMMISSION}

$\checkmark \quad$ appointed by the

- Federal Council of the Churches of Christ in America

The Department of International Justice and Goodwill 297 Fourth Avenue, New York 10, N. Y. 
Resolution approved by the Federal Council of the Churches of Christ in America, November 27, 1950

1. That the Federal Council of the Churches of Christ in America express deep appreciation to Bishop Dun and his colleagues for their report on "The Christian Conscience and Weapons of Mass Destruction."

2. That the report be printed by the Federal Council and commended to the Churches for careful study.

3. That the document be also referred for consideration to the National Council of the Churches of Christ in the U.S.A., when it comes into being.

The Department of International Justice and Goodwill 297 Fourth Avenue, New York 10, N. Y. Single Copy, 10 cents; $\$ 8.00$ per 100 copies 


\section{FOREWORD}

The executive committee of the Federal Council of Churches at its meeting on March 21, 1950 appointed a Commission to study the moral problems confronting the Christian conscience as a result of the increasing availability and use of military weapons of mass destruction. There were twenty members of the Commission as originally appointed. Of these, Professor Douglas V. Steere has been unable to take any part in the work of the Commission and bears no responsibility for our Report. The other members participated in the discussion and drafting which resulted in the Report here presented. In our task we were ably assisted by the Rev. Richard M. Fagley, who served as Secretary of the Commission.

The Report as presented has been signed by seventeen members of the Commission. Two members, Professor Robert L. Calhoun and Dr. Georgia Harkness, have appended brief statements of dissent from certain of the major portions of the Report.

As in the case of the earlier report of the Federal Council's Commission on "The Relation of the Church to the War in the Light of Christian Faith," issued in 1944, this Report cannot be viewed as a pronouncement in the name of the Churches. It is a word spoken by the signers on issues of dreadful seriousness and complexity; a word spoken, we trust, in the faith of the Church, to our fellow Christians and to others of our fellow men whom we may reach.

We worked under difficult time limitations in order to present our conclusions at the recent meeting of the Federal Council of Churches in Cleveland, Ohio on November 27, 1950. Whether we might have achieved greater clarity, given more time, cannot now be known. The reader should be reminded that the Report was prepared just prior to the present menacing extension of the conflict in Korea.

While we were asked to focus on questions directly related to military policy and to the use of particular weapons, we sought constantly to approach these questions in the light of the wider political and moral concerns of Christian conscience. Inevitably we found ourselves driven to stress the conviction that the only real hope lies in a courageous and costing program for the moral and political renewal of our sick world.

With a burdened sense of responsibility we present to our brethren the results of our all too brief wrestling with the questions referred to us. 


\section{MEMBERS OF THE COMMISSION}

Angus Dun, Chairman

Bishop of the Washington Diocese of the Protestant Episcopal Church

EDWIN E. Aubrey

Professor of Religious Thought, University of Pennsylvania

Chester I. Barnard

President, The Rockefeller Foun. dation

JOHN C. BENNETT

Professor of Christian Theology and Ethics, Union Theological Seminary

Conrad J. I. BergendofF

President, Augustana College

Robert L. Calhoun

Professor of Historical Theology, Yale University

ARThur H. Compton

Chancellor, Washington University

John R. Cunningham

President, Davidson College

Peter K. Emmons

Minister, Westminster Presbyterian Church, Scranton, Pa.

Theodore M. Greene

Master, Silliman College, Yale University
Georgia E. Harkness

Professor of Applied Theology, Pacific School of Religion

WALTER M. HORTON

Professor of Systematic Theology, Oberlin Graduate School of Theology

Benjamin E. Mays

President, Morehouse College

Albert T. Mollegen

Professor of Christian Ethics, Protestant Episcopal Theological Seminary of Virginia

JAMES H. NiCHOLS

Associate Professor of Church History, Divinity School, University of Chicago

REINHOLd NiEbUHR

Dean of the Faculty, Union Theological Seminary

George F. Thomas

Professor of Religious Thought, Princeton University

Paul J. Tillich

Professor of Philosophical Theology, Union Theological Seminary

WiLLIAM W. WAYMACK

Former Member, United States Atomic Energy Commission

Note: $A$ few editorial revisions have been made by the Chairman, in the interest of clarity, since the report was submitted to the biennial meeting of the Federal Council of Churches on November 27, 1950. 


\section{THE CHRISTIAN CONSCIENCE AND WEAPONS OF MASS DESTRUCTION}

We are a company of Christians called upon to look with open eyes at our human situation and at the powers of mass destruction now available to our nation and to other nations. We are asked to seek under God for a Christian word that might guide or strengthen our fellow Christians and our fellow men in the darkness we face together.

We are Christians who are also citizens of the United States. We cannot and would not escape from the responsibilities and the limitations of this destiny which we accept as God's purpose for us. Of necessity we must look out upon our world from where we stand. We cannot see with the eyes of Chinese men or men of India or men of Europe or of Russia. At the same time, we are called to lift up our eyes and try to see ourselves and our world in the light that comes from Him who hath made of one blood all nations of men to dwell on the face of the whole earth. And by His commandment of love we are called to identify ourselves with men of other lands in order that we may in some measure see through the eyes of those others. We are grateful for the growing opportunity which membership in the United Nations gives us as a nation, to act with other nations in the service of general human welfare and in the promotion of international justice and order. As Christians, we are grateful that we are helped by the world-wide Christian fellowship to look beyond ourselves, however imperfectly.

When we look out upon our world we see an ugly and unclean thing hanging over all the brightness and the good and even the shared sorrows and shared failures that make precious our human existence. It is not Christians alone or Americans alone who see this darkness or whose lives and homes and children and cities and laboriously built structures of common life are threatened by it. It is mankind that lives under this cloud. We Americans think in dread of what could happen tomorrow or five years from now to Chicago or New York or Washington. Frenchmen think of what could happen to Paris; Englishmen of what could happen to London; Russians of what could happen to Moscow. 
Because in our human wrongness we are self-centered, we think first and most often of what others might do to us and ours. And so it is with those others. Some of them think first and most often of what we might do to them. But as Christians we are compelled to think of what we might do or have done or even now are doing to others. For we cannot get out from under that commandment, "Thou shalt care for those others as thou carest for thyself."

\section{The New Dimensions of War}

This ugly thing, which we call war, hanging over our common humanity, is not something new. Through all man's tragic history he has suffered locally and periodically from war, family feuds, tribal wars, civil wars, religious wars, international wars. In Korea, as we have wrestled with this report, there have been fighting men and helpless, driven people whose whole existence has been flattened into shapelessness by a conflict to which we are parties. But the dimensions of the evil in any major conflict are now so heightened as to face us with something new.

It is as though the One who said to us, "They that take the sword shall perish by the sword", were pointing with inexorable logic to a Dead End towards which man's way of violence leads. Each stepping up of the powers of violence calls out more demonic ingenuity in matching destructive power with destructive power. Resistance to the use of more brutal weapons is broken through in a struggle for existence that at last threatens all existence. The means we have found of blowing up whole cities reveal mankind as in an inescapable community of danger and fear. The only real escape from these evils of war is the prevention of war.

Serious Christians of every name now see in war a grievous disclosure of man's lostness and wrongness. War destroys what God creates. It hurts those whom Christ came to heal. It mocks the love of God and His commandment of love. It is the stark opposite of the way of reconciliation. It breeds hatred and deception and cruelty.

Even in the face of that judgment we have to recognize that the overwhelming majority of Christians, after the earliest days when the Christian community was a little persecuted minority in a pagan society, without political responsibilities, have held that there are times when Christians should take the sword and fight as very imperfect servants of God's justice. They have acknowledged their responsibilities not only for peace within the Church, where the persuasions of love are most readily effective, but also 
for the maintenance of order and justice in civil society. There they have recognized the tragic necessity for coercive restraints on "the unruly wills and affections of sinful men", including their own. They have fought for what they believed was justice or good order or freedom, and against wanton aggression or enslavement. Often they have been swept heedlessly into the conflicts of the nations of which they were a part. The best among them have, like Abraham Lincoln, held fast to a recognition that God's justice and mercy stand high above all our human warfare; they have sought to show mercy even in conflict; and they have pressed for the speediest possible reconciliation when actual warfare ended.

Faced with the terrible ambiguities and compromises of fighting to serve even in so crude and soiled a way the more elementary demands of God's justice, sensitive Christians have sought to bring war itself under some restraints. In this they have certainly been joined by other men of good will. They have struggled to reduce or eliminate the savagery and sheer sadism that are set free by the madness of war. They have condemned the killing of prisoners and of hostages or the use of torture to gain military information. They have condemned the massacre of civilian populations, especially of women and children and the bombardment of "undefended" towns. They have sought to bring the radical lawlessness of war under some law.

Plainly what we now face in war and the threat of war and our involvement in it is an overwhelming break-through in the weak moral defenses erected to keep war in some bounds. At no point is this break-through more evident than in the widespread acceptance of the bombing of cities as an inescapable part of modern war. The industrial and technical potential of strong nations is now concentrated in cities. Their factories and power plants and fuel stores and transportation centers are their arsenals of war. It is forcefully argued that to destroy or cripple them by tons of "conventional" bombs or by raining fire upon them or by one atomic bomb is to strike at their fighting power as surely as to destroy an army or a fleet or an air force. In the harsh light of history, the best hope of preventing a global atomic war lies in preventing the recurrence of global war itself.

If global war comes, and with it a resort to still more powerful means of obliteration bombing, all of us will be caught up in it, men, women and children, believers and unbelievers, soldiers and civilians. Even those in the hills and on the plains may be drafted into it. In all soberness this is the grim possibility that hangs over us in rough proportion to the power and privilege of the people to which we belong. The safest places to be, as far as this threat 
is concerned, are the "backward" parts of the "backward" continents. It could well be that "the meek" will inherit the earth in an unexpected sense.

It is in this time and situation that we who profess and call ourselves Christians must make our decisions, for ourselves and as Churches, and that our nations and those who govern must make their decisions. And those of us who are Church people cannot divorce ourselves from those who carry for us the heavy burdens of political and military decisions.

\section{WAR AND WEAPONS OF MASS DESTRUCTION}

What are the decisions open to us?

The clearest and least ambiguous alternative is that urged upon us by our most uncompromising pacifist fellow-Christians. They believe that the refusal of all kinds of military service and an unqualified witness against war and for peace is for them the will of God. They would summon all Christian people and all Churches to unite with them in this witness. For them the infinitely heightened destructiveness and the morally catastrophic character of modern war confirm their conviction that followers of Christ can make no compromise with so great an evil. They find themselves called to follow the way of love and reconciliation at whatever cost and to accept the historical consequences of a repudiation of armaments and of war. For those who make this radical decision need for debate as to the choice of weapons is ruled out by a repudiation of all weapons.

Pacifist and non-pacifist Christians can probably agree that, as men are, responsible political leaders could not take the pacifist position and continue to hold positions of effective political leadership. But that fact does not relieve those of us who are Christians from making our own decisions in the sight of God and urging what we believe to be right Christian decisions on those who govern as our representatuves.

The large majority of professing Christians are not pacifists. But Christian non-pacifists share with their pacifist brethren abhorrence of war and with them see in it a sign of man's Godlessness. They agree that in all human conflicts the most righteous side is never so righteous as it thinks it is. They acknowledge that whatever good may ever come out of war, incalculable evil always comes out of it, too. We believe that God calls some men to take the way of non-violence as a special and high vocation in order to give a clearer witness to the way of love than those can give who accept responsibility for the coercions 
in civil society. We rejoice that God has called some of our brethren in the universal Christian fellowship to bear this witness and are humbled by the faithfulness of many in bearing it. Without minimizing the moral heroism it can require, we are even envious of the greater inner simplicity of that non-violent way.

But most of us find ourselves called to follow a course which is less simple and which appears to us more responsible because more directly relevant to the hard realities of our situation. And we believe it is the way in which most Christians must go.

There can be no justice for men and no responsible freedom without law and order. When men confront one another with their contending egotisms, without moral or spiritual bonds, they take the law into their own hands and work what is at best a very crude justice. They reach beyond that only when they have achieved some substantial moral community and a sovereign law rooted in moral community. This we have reached, however imperfectly, where we find ordered society. Even then the law which gives any just order must be sustained by power, and, when necessary, by coercive power.

The world we live in, the world of states and of great masses of men struggling up towards nationhood, is without strong uniting moral or spiritual bonds. It possesses no overruling law and in the United Nations an institution which marks only the beginnings of common order. In large measure our world is a "frontier" of self-regarding, mutually distrustful human masses. God's will for justice and for mercy broods over this disorder in which we find ourselves. We Christians believe that we are called to be the servants of His justice and His mercy. But can we be just to men if we do not struggle to maintain for them and for ourselves some order of justice in which good faith and freedom and truth can find a dwelling place? And can we extend the beginnings of this order in the United Nations, if we do not undergird it with effective power?

So most Christians, faced with the lawlessness of our world of nations, see no way of serving the righteousness of God in the presence of brutal and irresponsible violence save by taking responsible collective action against aggression within the framework of the United Nations. That we must do in fear and trembling, as those who know how our own self-interest blinds us. We must take upon ourselves the dreadful responsibilities of conflict, if we are to accept even the imperfect justice and freedom which others have painfully won and for which others fight and die even now. In the last resort we are in conscience bound to 
turn to force in defense of justice even though we know that the destruction of human life is evil. There are times when this can be the lesser of two evils, forced upon us by our common human failure to achieve a better relationship.

The deep disorder within men and among men, which Christian faith calls sin, leads to both brutal dominion and conflict. Today, two great dangers threaten mankind, the danger that totalitarian tyranny may be extended over the world and the danger of global war. Many of us believe that the policies most likely to avoid both dangers inevitably carry the risk of war.

Does this mear that for those who take this position the love of God and the judgments of God and the commandments of God cease to have meaning? We know that Christ died for our enemies as well as for us. We know that we are bidden to pray for our enemies as for ourselves. We know that we stand with them in need of forgiveness. We know that our failures to find another way of dealing with our deep differences and conflicts of interest and distrust of one another is a judgment on us and our forefathers as well as on them. But this does not extricate us from the hard realities of our situation.

We cannot lightly assume that a victory for our own nation, or a victory for the United Nations, is in itself a victory for God and His righteousness. Even in war we cannot rejoice that more of the enemy are killed than of our own people. Even in victory we can rejoice only if, from the sacrifices of so much life, some little gain is made for order and freedom, and renewed opportunity is found for mercy and reconciliation.

\section{Concepts of Total War}

Christians who have decided that in the last resort they may be compelled to accept the terrible responsibilities of warfare are now confronted with these questions: Does that mean warfare without any limits? Does that mean warfare with any weapons which man's ingenuity can provide?

War has developed rapidly in the direction of "total war" in two meanings, which it is important to distinguish.

In the first meaning total war refers to the fact that in a conflict between highly industrialized nations all human and material resources are mobilized for war purposes. The traditional distinction between combatants and non-combatants is far less clear. Only small children and the helpless sick and aged stand outside the war effort. It is practically impossible to distinguish between guilty and innocent. Certainly men who are drafted into 
uniform may be among the least guilty. Total war, in this sense of the involvement of the whole nation in it, cannot be avoided if we have a major war at all.

Total war, in the second sense, means war in which all moral restraints are thrown aside and all the purposes of the community are fully controlled by sheer military expediency. We must recognize that the greater the threat to national existence the greater will be the temptation to subordinate everything, all civil rights, the liberty of conscience, all moral judgments regarding the means to be used, and all consideration of postwar international relations, to the single aim of military victory.

Christians and Christian Churches, if they admit that occasions can arise when the use of military force by a nation or a group of nations may be less evil than surrender to some malignant power, cannot deny that total war in the first sense may be inescapable.

But Christians and Christian Churches can never consent to total war in the second sense. The only possible justification for war is that it offers a possibility of achieving a moral result, however imperfect, to prevent an overwhelming moral evil and to offer a new opportunity for men to live in freedom and decency and in just and merciful relationships.

Christians certainly, and humane men of any faith, if they find themselves driven to hurt, will hurt as little and as few as possible; and if they find themselves driven to kill, will seek to restrict killing within the harsh necessities determined by their total goals, military, political, and moral. Military victory is not an end in itself. Just as death is preferable to life under some conditions, so, too, victory at any price is not worth having. If this price is for us to become utterly brutal, victory becomes a moral defeat. Victory is worth having only if it leaves us with enough reserves of decency, justice and mercy to build a better world and only if it leaves those we have conquered in a condition in which they can ultimately cooperate in the task of setting forward God's purpose in creation. Hence the way we fight and the means we use are of crucial importance. And these will be determined by the spirit in which we fight and the purposes for which we fight. Military expediency, therefore, cannot be the sole test, but must be subordinated to moral and political considerations.

Any people who in the savagery of war kill and destroy without reckoning will stand under the condemnation of our common humanity and surely under the condemnation of God. The concept of "atrocities" does not lose its meaning, merely because 
all war is brutal. Torture and killing of prisoners is more inhuman than wounding and killing in combat. The fact that industrial workers and women and children live in the areas surrounding major industrial plants compels us to reckon with the death and maiming involved for them in striking at industrial targets. And we cannot forget that the destruction of the industrial fabric of a human community can make almost impossible the recovery of decent and ordered existence, after victory in a military sense has been won.

\section{The Weapons of Mass Destruction}

What then of the weapons we shall or shall not be prepared to use?

Can we find some absolute line we can draw? Can we say that Christians can approve of using swords and spears, but not guns; conventional bombs or jellied fire, but not atomic bombs; uranium bombs, but not hydrogen bombs? Can we say that Christians must pledge themselves or seek to pledge their nations not to stock this or that weapon, even though the enemy stocks them; or not to use some weapons, even though the enemy uses them?

We find no "clean" methods of fighting, but some methods are dirtier than others. Some cause more pain and maiming without commensurate military decisiveness. Some are more indiscriminate.

We have no more - nor any less - right to kill with a rifle or a bazooka than with an A-bomb or an H-bomb. In the sight of Him, "to whom all hearts are open", the inner quality of an act is to be distinguished from its consequences. There may be more hatred and less penitence in the heart of a man who kills one enemy with a rifle, or in the heart of a frenzied super-patriot in his arm chair, than in the heart of an airman who devastates a city with a bomb. Sin in its inward meaning cannot be measured by the number of people who are affected. But a reckoning of consequences is also a part of a Christian's decision. It is more dreadful to kill a thousand men than one man, even if both are done in the service of justice and order. We cannot, therefore, be released from the responsibility for doing no more hurt than must be.

Here a distinction can be drawn between precision weapons, which can be directed with reasonable control at primary military objectives, and weapons of mass destruction. But we are compelled to recognize that the increasing distance from which bombs or projectiles are released and the speed of planes and guided 
missiles are likely to offset all gains in precision. If, as we have felt bound to acknowledge, certain key industrial targets are inescapably involved in modern war, we find no moral distinction between destroying them by tons of T.N.T. or by fire as compared with an atomic bomb, save as greater precision is possible in one as compared with others. But this recognition that we cannot isolate the atomic bomb or even the projected $\mathrm{H}$-bomb as belonging to an absolutely different moral category must not blind us to the terrible dimensions of the moral problem they present.

With a single atomic bomb, destruction is produced that is as great as that from a large fleet of airplanes dropping conventional explosives. If the H-bomb is made, it will be destructive on a still more horrible scale. If such weapons are used generally upon centers of population, we may doubt whether enough will remain to rebuild decent human society.

But the abandonment of atomic weapons would not eliminate mass destruction. Conventional or new weapons may produce comparable destruction. The real moral line between what may be done and what may not be done by the Christian lies not in the realm of the distinction between weapons but in the realm of the motives for using and the consequences of using all kinds of weapons. Some measures corrupt the users, and destroy the humanity of the victims. Some may further the victory but impair the peace. There are certainly things which Christians should not do to save self, or family, or nation, or free civilization. There seems to us, however, no certain way to draw this moral line in advance, apart from all the actual circumstances. What may or may not be done under God can be known only in relation to the whole, concrete situation by those responsibly involved in it. We can find no moral security, or moral hiding place, in legalistic definitions. The terrible burden of decision is the Christian man's responsibility, standing where he does before God.

Nevertheless, real distinctions can be made to illumine and help the conscience in its trouble. The destruction of life clearly incidental to the destruction of decisive military objectives, for example, is radically different from mass destruction which is aimed primarily at the lives of civilians, their morale, or the sources of their livelihood. In the event of war, Christian conscience guides us to restraint from destruction not essential to our total objectives, to a continual weighing of the human values that may be won against those lost in the fighting, and to the avoidance of needless human suffering.

Unhappily we see little hope at this time of a trustworthy international agreement that would effectively prevent the manu- 
facture or use of weapons of mass destruction by any nation. This should not deter us from the search for such an agreement, perhaps as a part of a general disarmament program, and for a restoration of mutual confidence that would make an agreement possible and effective.

As long as the existing situation holds, for the United States to abandon its atomic weapons, or to give the impression that they would not be used, would leave the non-communist world with totally inadequate defense. For Christians to advocate such a policy would be for them to share responsibility for the worldwide tyranny that might result. We believe that American military strength, which must include atomic weapons as long as any other nation may possess them, is an essential factor in the possibility of preventing both world war and tyranny. If atomic weapons or other weapons of parallel destructiveness are used against us or our friends in Europe or Asia, we believe that it could be justifiable for our government to use them with all possible restraint to prevent the triumph of an aggressor. We come to this conclusion with troubled spirits but any other conclusion would leave our own people and the people of other nations open to continuing devastating attack and to probable defeat. Even if as individuals we would choose rather to be destroyed than to destroy in such measure, we do not believe it would be right for us to urge policies on our government which would expose others to such a fate.

Having taken the position that no absolute line can be drawn we are especially concerned to emphasize checks on every step towards the increased destructiveness of war.

To engage in reckless and uncontrolled violence against the people of any other nation is to reduce the possibilities of peace and justice and freedom after the war's end and even to destroy the foundation of ordered society. Military judgment must not yield to the vengefulness that too often possesses civilians in wartime; nor must the national government yield to the military its own responsibility for the immediate and the postwar consequences of the conduct of the war.

We have recognized that indiscriminate mass destruction may be caused by atomic bombs or by a fleet of armored tanks or by a ruthless army laying waste cities and countryside. We have found no moral distinction between these instruments of warfare, apart from the ends they serve and the consequences of their use. We would, however, call attention to the fact that the first use of atomic weapons in another war, even if limited to sharply defined military targets, would open the way for their use in retaliation. Because of the very power of these weapons, 
it would be difficult to prevent their use from extending to military targets that would involve also the destruction of noncombatants on a massive scale. If the United States should use atomic weapons, it would expose its allies to similar attack. The nation that uses atomic weapons first, therefore, bears a special burden of responsibility for the almost inevitable development of extensive mass destruction with all its desolation and horror.

Even more fundamental, the dreadful prospect of devastation that must result from any major war illuminates with special clarity the immorality of those in any country who initiate an aggression against which the only effective means of defense may be the resort to atomic weapons, and which may thus be expected to lead to an atomic war. If general war comes it will probably be a war for survival, not only for the survival of a free civilization, but for the physical survival of peoples. In such a war the temptation will be tremendous to forget all other considerations and to use every available means of destruction. If this happens, physical survival may be bought at the price of the nation's soul, of the moral values which make the civilization worth saving.

\section{PEACE AND A POSITIVE StRATEGY}

Just because the choices open to us on the plane of war appear so tragic and offer so little hope, we are firmly convinced that the way out of our darkness must be sought, not primarily by limiting some one or other weapon, but on the political and moral plane. The weapons already in our hands and in the hands of others heighten immeasurably our fear and distrust and grievously complicate our political problem. But war itself and the malignant sickness of our human relationships are at the center of our trouble.

By dread of the death that threatens us and ours, and equally our fellows in other lands; even more, by dread of the moral catastrophe before which we stand, God calls us Christians and us Americans to a deeper self-searching than we have yet known and to a more bold and imaginative, even adventurous, seeking from Him of the way of life.

Though certainly we shall not be saved by weakness, we shall not be saved by military power alone. A one-sided concentration on military measures can easily lead to disaster.

The avoidance of global war without surrender to tyranny is the one great issue overriding all others. 


\section{The Rejection of Preventive War}

To avoid the physical and moral disaster of global war we must put behind us as a satanic temptation the dangerous idea of a "preventive war", which is closely bound up with the faithless and defeatist idea that war is inevitable.

Since we are in a situation of acute international tension well described as a "cold war," there are those who suggest that it is neither important nor possible to distinguish between that situation and overt conflict. "We are already at war in fact," they say. "Let's have it out and have it over." This appeals partly because it offers a release into action from a wearing state of anxiety and day-by-day irritation. But there is this great difference between open conflict and our present tensions, namely, that the latter do not involve the mass destruction and the moral debacle of global war. Just because that difference is so great no nation which subordinates national policy to moral purpose can think of beginning a general war, however uncomfortable and frustrating the present situation is.

There are those who argue that "cold war" must lead inevitably to "hot war". With modern methods of mass destruction the striker of the first blow may have a great advantage. "Let us," they say, "choose the time most favorable to our cause and gain the advantage of striking the first blow."

To accept general war as inevitable is to treat ourselves as helpless objects carried by a fated tide of events rather than as responsible men. The fact that many things in history are probable does not make them inevitable. One reason why fascism and nazism gained their dread power over great nations was because otherwise decent people bowed before what they regarded as "inevitable" and allowed a "wave of the future" to inundate them. Just because the probable results of general war with atomic weapons are so terrible no God-fearing people can take the responsibility for initiating a war which cannot be fought successfully without their use. "Woe unto the world because of offenses: for it must needs be that offenses come; but woe to that man by whom the offense cometh."

A fatalism and defeatism which assumes the inevitability of war with world Communism deflects us from the very strategy which offers us the greatest hope of any real victory; namely, the building up of the economic and social and moral health of the areas in our world not already under complete Communist domination. For Communism is more than the tyranny and imperial ambitions of the Soviet rulers. It is also a political religion, whose promises of a universal, classless society, tragically per- 
verted though they have been, still carry a dynamic appeal to those oppressed by harsh and unjust conditions. To overcome such conditions requires positive non-military measures.

Thus to accept the inevitability of war is strategically wrong. It is morally wrong because it is a surrender to irresponsibility. It is religiously wrong because it involves a pretension on the part of man to know the future with an assurance not granted to man.

A second argument for a "preventive" war is based on the idea that Communism is an evil so monstrous that the evils even of a general conflict are not too high a price to pay for its elimination. If Communism should press hostilities against the non-communist world we would undoubtedly continue to resist, even though we could not measure the ultimate consequences. But precisely because this is true, we must insist the more that we have no right to initiate, by our own act, a struggle with such incalculable consequences. When decisions are forced upon us, we must act with faith and courage even if we cannot measure ultimate consequences. But consequences which will be horrible according to responsible calculation, and may be more terrible than any calculations, cannot be morally justified, if the decision rests with us.

A further reason for rejecting the idea of a preventive war is that even if the Soviet Union were defeated in such a war, that would not necessarily mean the defeat of communism, much less the successful defense of democracy. The world in the aftermath of such a war would be ripe for anarchy or for totalitarian movements promising men bread and security, rather than for the freedoms we seek to extend.

\section{The Need for Democratic Strength}

To build up and maintain adequate strength in the free world - yes, military strength, but military strength undergirded as it must be by economic and political and moral health - will make tremendous moral demands on the people of the United States and other members of the United Nations. For America even to maintain over a long period adequate military strength, let alone support bold strategies for strengthening economically and socially our less fortunate neighbors, without the obvious incentive of war itself, will call for self-discipline and resolution and a tightening of our belts such as we have never achieved. It is futile to argue with those who urge a desperate try for a quick decision because they do not believe we can rise to such demands, unless we are prepared to support the policies of armament and preparedness and of taxation and consumption restraints re- 
quired for the maintenance of adequate strength in the free world. Whether or not we can avoid atomic devastation of the world in which we and our children dwell can well depend on the readiness of Americans to have fewer washing machines and television sets and automobiles for the sake of an all-out girding for the responsibilities laid upon us.

We should not and we do not rule out the possibility of an ultimate stability in the world situation. But we are quite clear that no significant agreements can be made with world-wide Communism so long as it assumes that it can violate the decisions of the United Nations with impunity and success. We believe in a moral approach to our problem, but a moral approach is one which accepts responsibly the full burdens imposed by the situation in which we find ourselves.

Since we believe that peace in the world, like peace in major human communities, must be sustained by power, we believe that peace in our world can be preserved only by the strength of the free world. This includes military power. But moral and political strength is ultimately a larger factor than military strength. Military strength is simply the hand, and the hand belongs to an arm and a body. Political and moral strength are the arm and body. If the moral and political struggle with Communism is lost, no military strength will avail.

Therefore the faith that sustains American life and the moral vitality of our society and the enthusiastic commitment that we can win from our people are of supreme importance. In the trials of our time every American who lives irresponsibly, who seeks his own gain without counting the cost to others; every politician who plays recklessly for partisan advantage or his own advancement; every injustice in our common life, every hyprocrisy in our democratic professions, weakens us and makes us less ready to fulfill the role laid upon us by reason of our power.

If we are to maintain and renew the political and moral health of our nation, Christians must stand firmly against public hysteria and against all attempts to exploit the fears of our people in these critical days. The sensational or self-righteous distortion of truth, the slanderous defamation of men in public life, the attacks upon hard-won freedoms and the safeguards of our Constitution - these divide and weaken our nation in the face of grave external dangers. They point in the direction of the police state methods we oppose. They rob us of the steadfast will to carry through our world responsibilities. They tend to make impossible a far-sighted and constructive strategy for peace. In the midst of the fears and frustrations of our new insecurity, the Churches of Christ must stand as guardians of freedom, as well as of faith. 
Christians must never allow themselves to become complacent about America or the Western societies. It would be a fatal mistake to defend every aspect of our institutions, merely because they are under violent attack by Communist propagandists. Democratic strength requires self-criticism, a willingness to confront the facts with open eyes, and a determination to improve the application of democratic principles to our common life.

Above all, our Churches must be concerned for the spiritual foundations of democratic strength. Ultimately the strength that avails is the power of the Lord, and we are ill prepared for the evil day unless we have the armor of God. With freedom in worldwide jeopardy, the Church must lead men and women to the true source of freedom, that He who makes us free may be our constant guide.

And next to the quality of the common life we bring to the issues of our time is the role we are able to play in helping other nations to gain physical well-being and moral vigor in freedom. The life-giving qualities of the free world, if vigorously renewed, can provide the surest human defense against tyranny and war. If the vitality, integrity, and neighborliness of the democratic societies can be developed and demonstrated in convincing ways, the Soviet rulers may find a modification of their expansionist aims, or at least of their intolerant methods, to be expedient. That would provide new opportunity for bridging the gulf between the Soviet and Western worlds with understanding and more reliable agreements.

Only a bold and imaginative strategy, supported by self-discipline and devotion, has a chance of success. There are no sure patterns of action to enhance the inner and outward strength of the non-Soviet world. Rather, there must be a willingness to try new and uncharted courses of constructive action which offer reasonable promise.

The policies pursued need to be convincing on two basic points. They must carry conviction that the non-Soviet societies are morally impregnable to totalitarian infiltration, as well as militarily strong enough to make overt aggression too hazardous. On the other hand, they must also carry conviction that the goal of the West is peace and not the conquest or forcible conversion of the Soviet Union. This means that the dominant motives of peace strategy should be positive and creative, and that every opportunity to develop friendly contacts with the Soviet peoples, or to draw Soviet representatives into the constructive activities and fellowship of the non-Soviet nations, should be utilized. On this, most Christian pacifists and non-pacifists can agree. 


\section{Elements of a Positive Peace Program}

In the forefront of a positive peace program is the plan to provide technical assistance and help secure financial assistance for the development of underdeveloped nations. This plan to attack in a concerted way the ancient enemies of ignorance, hunger, and disease, by concentrating available scientific and material resources on areas of greatest need, has aroused new hope around the world. Its scope and creative purpose have stirred the imaginations of men and enlisted their support.

We recognize the many and stubborn difficulties which beset, and will continue to beset for many years, a program such as this. But we believe it provides a means for combatting the conditions in which totalitarianism finds fertile soil. It provides an opportunity for joining the efforts of nations in a common interest which promotes international fellowship. It invites, although it does not require, the cooperation of the Soviet Union. This United Nations program should be supported vigorously by our government, and be reinforced at every appropriate point by our Churches and mission boards.

We are grateful for the pioneering work done by missionaries. Educational missions seeking the enlightenment of entire peoples, medical missions bringing health freely to all in need, and preaching missions offering a Gospel which gives meaning to life and death - these are the best values of our culture. These are treasures the Christian fellowship can contribute to a positive peace program.

In all the confusing complexities of our world-political problems we can discern some broad outlines. The hard core of our grievously disturbed relationships is in the constantly mounting tension between ourselves and Soviet Russia and her satellites. All can agree that this is the hardest to change. But Russia and the United States do not stand alone. The power of either to hurt the other decisively depends greatly on the direction taken by other communities of men, in the East as well as the West.

In Eastern Asia and the Pacific area there are millions of men struggling up out of poverty and ignorance. The failure of Communism to capture Western Europe has accentuated its activities in the East. There vast social confusion, due to the disintegration of the colonial system and the impact of technical civilization on backward economies, and the resentment of colored peoples against the white world give Communism a fertile field in which to sow its false promises to desperate peoples. In dangerous measure the Communists have captured the leadership of this revolution of depressed masses against ancient privilege. Rice and land they can call their own and a chance to stand among men 
in their own right mean more to them than our slogans of freedom or free enterprise. We have to offer them something better than "free privilege" or unrestricted freedom for gain. We need to make it clear that our democratic constitution is Christian in background just because it is founded upon restraints, not upon doctrinaire freedom.

These peoples have suffered for generations the indignity of being treated by white men as "inferior breeds." Just because man is a spiritual being, the indignity of treatment as an inferıor rankles more bitterly than physical deprivation. These peoples find it hard to trust us. Their resentments are awakened by every indignity imposed upon Jews or Negroes or Orientals or Mexicans or American Indians. A chance to live as equals and the millenial promises of Communism for rice and land have fired the awakening hopes of the Asiatic peoples. It is not enough to say complacently that we are working to eliminate discriminations against racial and religious minorities and that it will take time. It will take time, but we need to work at it harder, determined to succeed in the shortest time possible. Renewal of our own way of life and a sustained effort to help the peoples of other lands achieve a better way of life than is possible under totalitarianism - these must be the goals of our strategy.

In Western Europe and the Atlantic area there are the peoples out of which our own inheritance has come most directly. With them, in spite of all strain and even past wars, we have a fuller basis for understanding and greater moral community than with any others. They have suffered the impoverishment and devastation of two world wars fought over their fields and cities. They now stand between the two great centers of power. They fear that if they must be rescued by us they shall be a waste land. And ordinary men will take their chances with much tyranny if the only alternative they can see is a waste land.

In our common peril, we desperately need the friendship of these peoples, too, and their strength. To win that we must give them the confidence that we understand them and how they are placed and that in full truth we make common cause with them. We shall not win that confidence if they can reasonably suspect that we seek to build them up to be buffers between us and the great center of power we fear, instead of seeking the welfare of their peoples for themselves. Our pride and our assurance that we know so much better than they how things should be done and our impatience are constant threats to the winning and holding of this confidence. We and they share a common destiny. Together we are called to meet it in comradeship.

Even in the case of Russia, in the face of the crass effrontery 
and the baffling falsity of her spokesmen, we cannot afford to accept the assumption that there is nothing human and good and real there to which we could speak. The Russian people share our common human needs and fears and hopes and sensibilities. They too, we are sure, want peace, if for no other reason than that like us they have such a dread of war. We must ask ourselves again and again, "Have we exhausted every means of speaking to them and of saying to them that we do not desire to destroy them or to take their land from them or to convert them by force? Have we repudiated in ourselves the things we have done or the things said in our name that could make it plausible to the people of Russia that we will their destruction?"

We have no clever new political stratagem to offer. But in the sight of God we are persuaded that our desperate times call for a mighty and costly drive for the political and moral revival and uniting of the free world and beyond that for reconciliation. That must accompany and even speak louder than our resolve to be strong. Are we conscripting the best intelligence and the most disinterested good will that America possesses for this supreme task? Are we Americans willing to spend and be spent for peace even more than for war?

The special task of the Churches in our time as in every time is to cry out to men, "Behold your God". It is in beholding Him and in standing in penitence before Him that we can gain and regain our moral stature as responsible men. In Him alone we can find the forgiveness without which our moral burden would be intolerable. And in receiving His forgiveness we can win the power to forgive those who trespass against us. Beholding Him, we can be delivered from the ultimate fears and the hysteria out of which no wisdom can come for meeting the terrors of our time. Before Him we dare to believe that we have a citizenship which no human weapons can destroy. From Him who "would fold both heaven and earth in a single peace" there comes even in our darkness that strange word, "Be not anxious."

Signed:

Angus Dun, Chairman

EdWin E. Aubrey

Chester I. Barnard

JOHN C. BENNETT

ConRad J. I. Bergendoff

ARTHUR H. CoMpton

John R. Cunningham

Peter K. EMmons

Theodore M. Greene
WALTER M. HoRTON

Benjamin E. Mays

Albert T. Mollegen

JAMES H. Nichols

Reinhold NiebUhr

George F. Thomas

Paul J. Tillich

William W. WAYMack 


\section{Statements by Two Members Of The Commission}

The chairman and my other colleagues have graciously suggested that I add a brief note to indicate why I cannot join them in signing the statement on which we have worked together. With much of it, needless to say, I am in hearty accord. Most of what is said in the introduction and second main section seems to me sound and admirable.

But on the most central issue, the statement seems to me still involved in deep-going confusion. On the one hand, it is repeatedly affirmed that "victory at any price is not worth having," that "military expediency" is not an adequate test for conduct in wartime. But in fact this turns out to be the only practically effective test that is consistently urged; and the only wartime practice that is consistently condemned is wanton cruelty or destruction "without commensurate military decisiveness." Concern for social and political welfare after a war does not rule out military measures that may well preclude it. Christian conscience in wartime is assigned the negative, inhibitory role of suggesting "restraint" on destructive procedures. But the norm for practically effective inhibitions turns out to be, after all, military decisiveness; and beyond ruling out wanton destruction, Christian conscience in wartime seems to have chiefly the effect (certainly important but scarcely decisive) of making Christians do reluctantly what military necessity requires. The ruling assumption throughout, it seems to me, is that if "we" are attacked, we must do whatever is needed to win.

This perspective may be defended on political and cultural grounds. It can scarcely be regarded as distinctively Christian. Still less is it ecumenical. It represents a majority view, not an inclusive common mind. We who have worked together on this statement have not failed in earnestness, candor or charity. But I think all of us have failed, thus far, to achieve the wisdom and clearness needed to make our statement a valid whole.

\section{Robert L. Calhoun}

I assent to the introduction and second main section of the statement but feel obliged to withhold my signature from the intervening section on "WAR AND THE WEAPONS OF MAsS DesTRuCTION." My reasons are: (1) Christian pacifism as an attempt to eliminate war through international reconciliation is less simple and more responsible than is here suggested. (2) Under conditions of modern warfare the restraints proposed are largely inapplicable. To say that our government might justifiably use atomic weapons in retaliation "with all possible restraint" seems a contradiction in terms. (3) Although the general tone of the document is deeply and movingly Christian I do not find in this section such distinctive moral guidance from the Christian Gospel as I believe to be both possible and necessary. 
